\title{
The Archaeology of the Middle Caddoan Period in the Middle Red River Valley of Northeast Texas
}

Timothy K. Perttula

Heritage Research Center, Stephen F. Austin State University

Follow this and additional works at: https://scholarworks.sfasu.edu/ita

Part of the American Material Culture Commons, Archaeological Anthropology Commons, Environmental Studies Commons, Other American Studies Commons, Other Arts and Humanities Commons, Other History of Art, Architecture, and Archaeology Commons, and the United States History Commons

Tell us how this article helped you.

This Article is brought to you for free and open access by the Center for Regional Heritage Research at SFA ScholarWorks. It has been accepted for inclusion in Index of Texas Archaeology: Open Access Gray Literature from the Lone Star State by an authorized editor of SFA ScholarWorks. For more information, please contact cdsscholarworks@sfasu.edu. 


\section{The Archaeology of the Middle Caddoan Period in the Middle Red River Valley of Northeast Texas}

\section{Creative Commons License}

\section{(c) (1) \&}

This work is licensed under a Creative Commons Attribution-NonCommercial 4.0 International License 


\section{The Archaeology of the Middle Caddoan Period in the Middle Red River Valley of Northeast Texas}

\section{Timothy $\boldsymbol{K}$. Perttula}

Middle Caddoan period sites (estimated to date from ca. A.D. 1100-1300/1350; see Bruseth et al. 1995) in the Middle Red River Valley of Northeast Texas appear to have cultural affiliation with the Sanders phase/focus originally recognized by Krieger (1946). Sanders phase components are distributed in the Middle Red, Kiamichi, and Upper Sabine River basins of Southeast Oklahoma and Northeast Texas (see Bruseth et al. 1995:Figure 3). In the Middle Red River valley, key components include the A.C. Mackin (4ILR36), Fasken (41RR14), Roitsch (41RR16; previously known as the Sam Kaufman site), Holdeman (41RR11), Sanders (41LR2), and Harling (41FN1) sites.

Middle Caddoan period settlements along the Middle Red River include dispersed farmsteads and hamlets with structures, middens, and cemeteries, as well as large communities such as the Roitsch and Holdeman sites with single and multiple mounds; substructure mounds; flat-topped platform mounds; and burial mounds (see Perino 1995; Hamilton 1997). Sites include from one to as many as three mounds at the larger communities or villages. Burials in mound and non-mound contexts were typically in extended supine position, with large numbers of grave goods in association. At the Holdeman site, for example, Sanders phase burials contained an average of 6.5 grave goods, mainly ceramic vessels, per individual (Perttula 1995:Table 1), with even more substantial grave good associations (shell conch dippers, gorgets, and beads, bone beads, projectile points, and ceramic vessels) from Class I and II burials at the Sanders site (Hamilton 1997:Table 2).

In regards to the subsistence pursuits of the Middle Caddoan populations in the Middle Red River Valley, tropical domesticates (maize) are present in archaeological context. Stable carbon isotope data from the Holdeman and Sanders sites suggests that the dependence on maize was not uniform, and ranged from an apparently high dependence at Sanders (Wilson and Cargill 1993), but not necessarily so at Holdeman ca. A.D. 1200 (stable carbon isotope data on file, Division of Antiquities Protection, Texas Historical Commission, Austin). Dental paleopathologies at the Sanders site confirm the fact that the Sanders population had a carbohydrate-rich diet (Wilson 1997), and caries are also common in the Holdeman site dentition (Loveland 1987, 1994).

Among the lithic artifacts found in Middle Caddoan period contexts are Bonham, Morris, and Scallorn sattler arrowpoints (Figure 1), grinding stones, flake tools, celts, and sandstone abraders (Krieger 1946; Perino 1995). There are long-stemmed Red River, Haley variety pipes, as well as clay and stone elbow pipes present (Figure 2a-b), and a wide assortment of ceramic vessels.

In general, vessels of the types Canton Incised, Maxey Noded Redware/blackware, Paris Plain, Sanders Engraved, Sanders Plain are relatively common in Middle Caddoan period contexts in the middle reaches of the Red River, along with East Incised (Figures 3-4) and Monkstown Fingernail Punctated. At the Sanders site, for example, of the 461 classified vessels, Sanders Engraved accounts for 15.8 percent of the assemblage; Canton Incised accounts for 29.1 percent; Maxey Noded Redware accounts for 8.3 percent; and redslipped plain (Sanders Plain) bowls comprise another 4.6 percent of the assemblage (Krieger 1946:Table 5). More than 15 percent of the vessels at the site have a red slip. At the Holdeman site, 23 percent of the Sanders phase vessels have a red slip, plain V-shaped and carinated bowls and jars are very common (comprising 67 percent of the 109 vessels in 

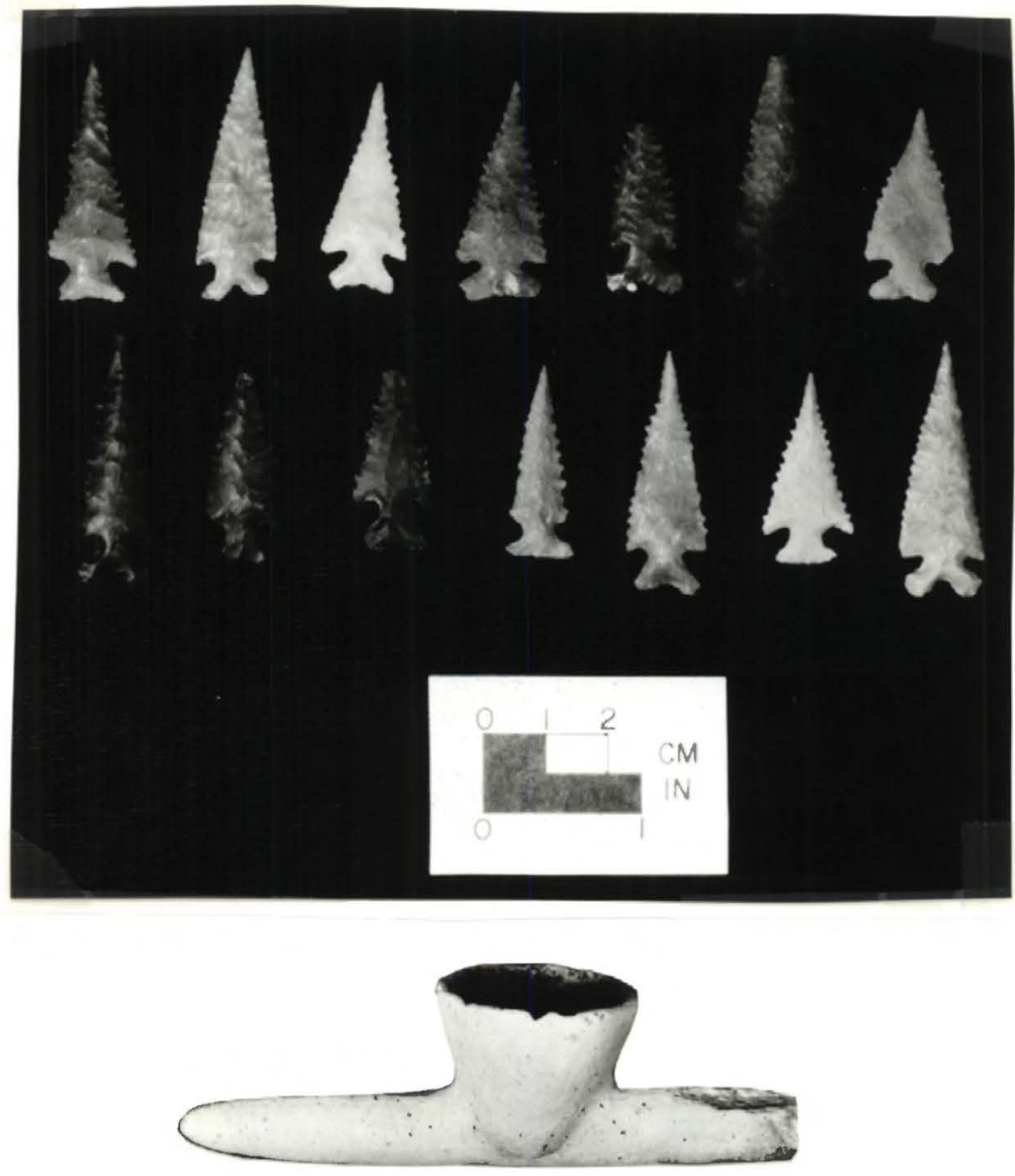

A

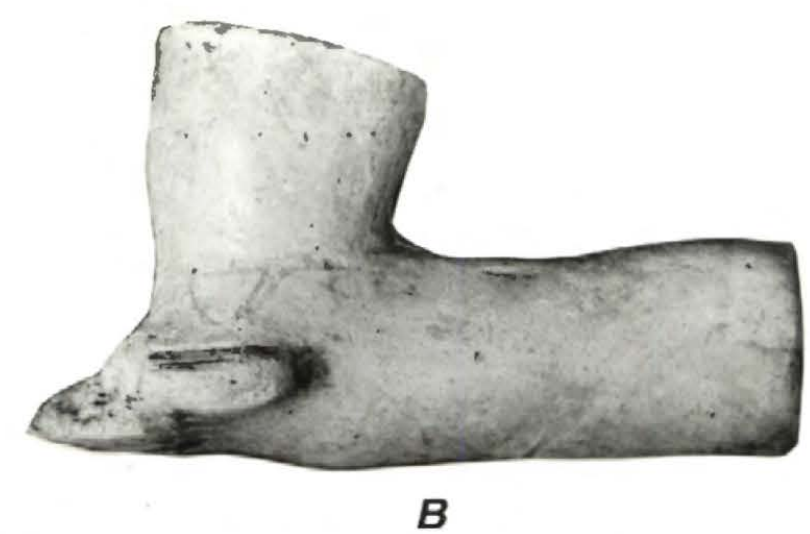

Figure 1. Morris Arrowpoints from the Holdeman Site. Figure 2. Clay Pipes. 


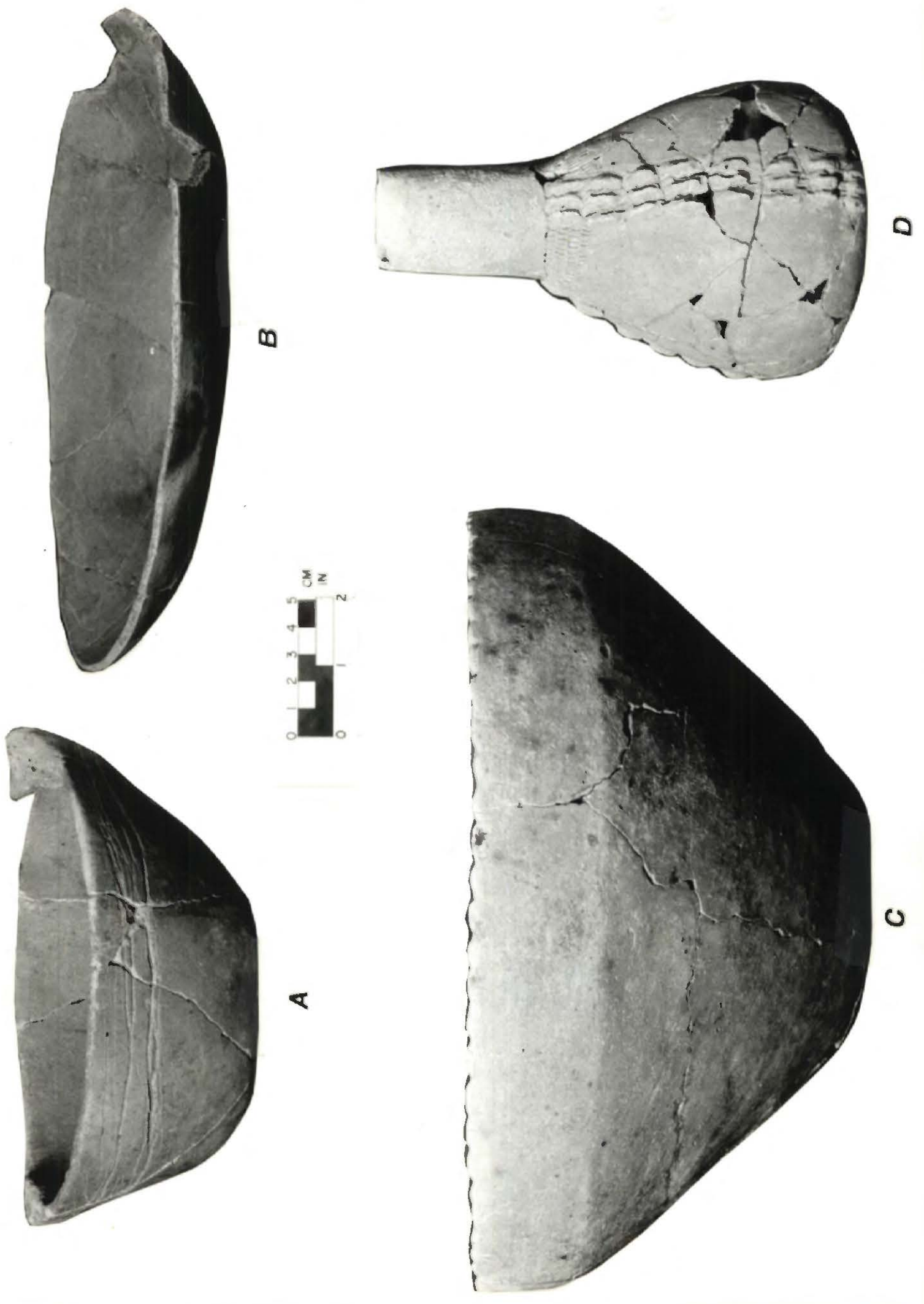

Figure 3. Vessels from Middle Caddoan Contexts at the Dan Holdeman Site: a, East Incised; b, large reused bowl; c, Sanders Plain; d, Maxey Noded Redware. 

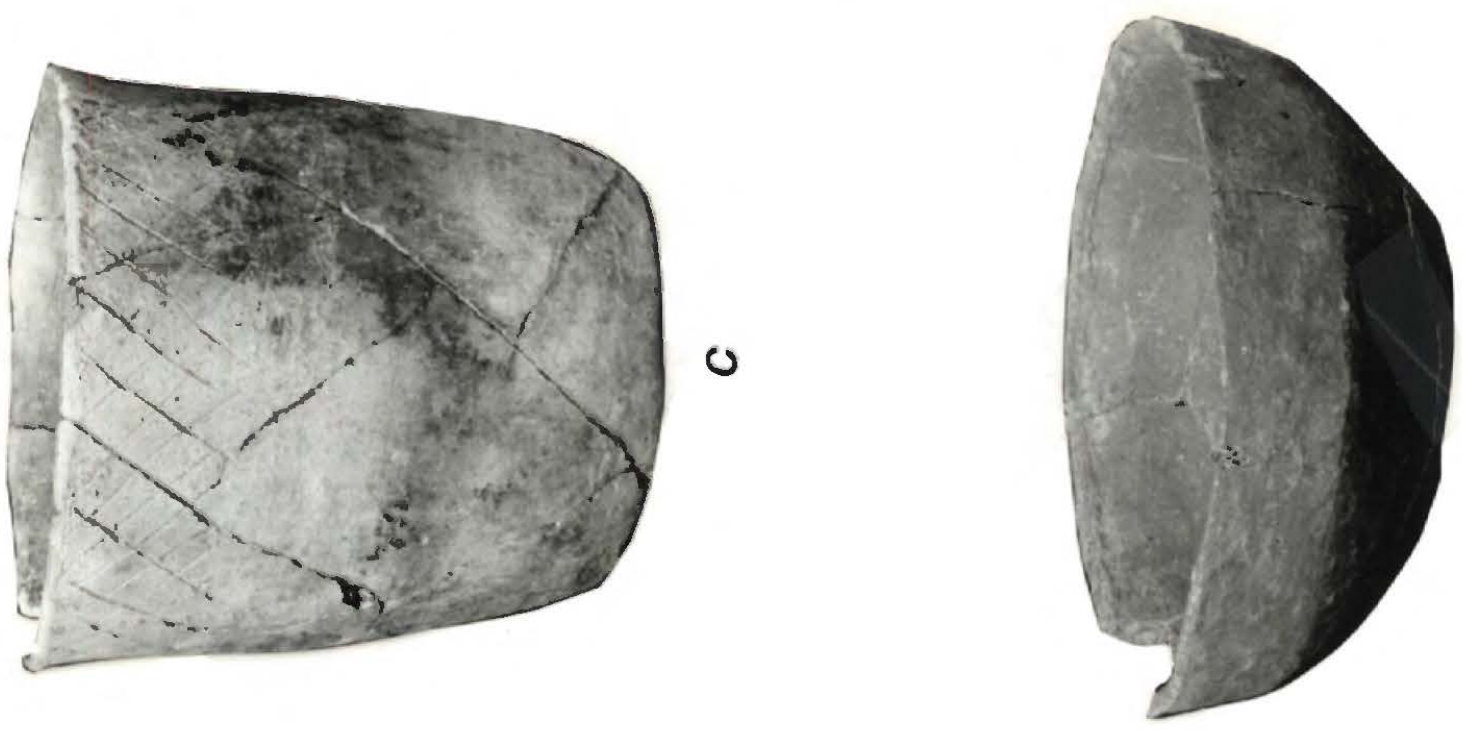

$u$
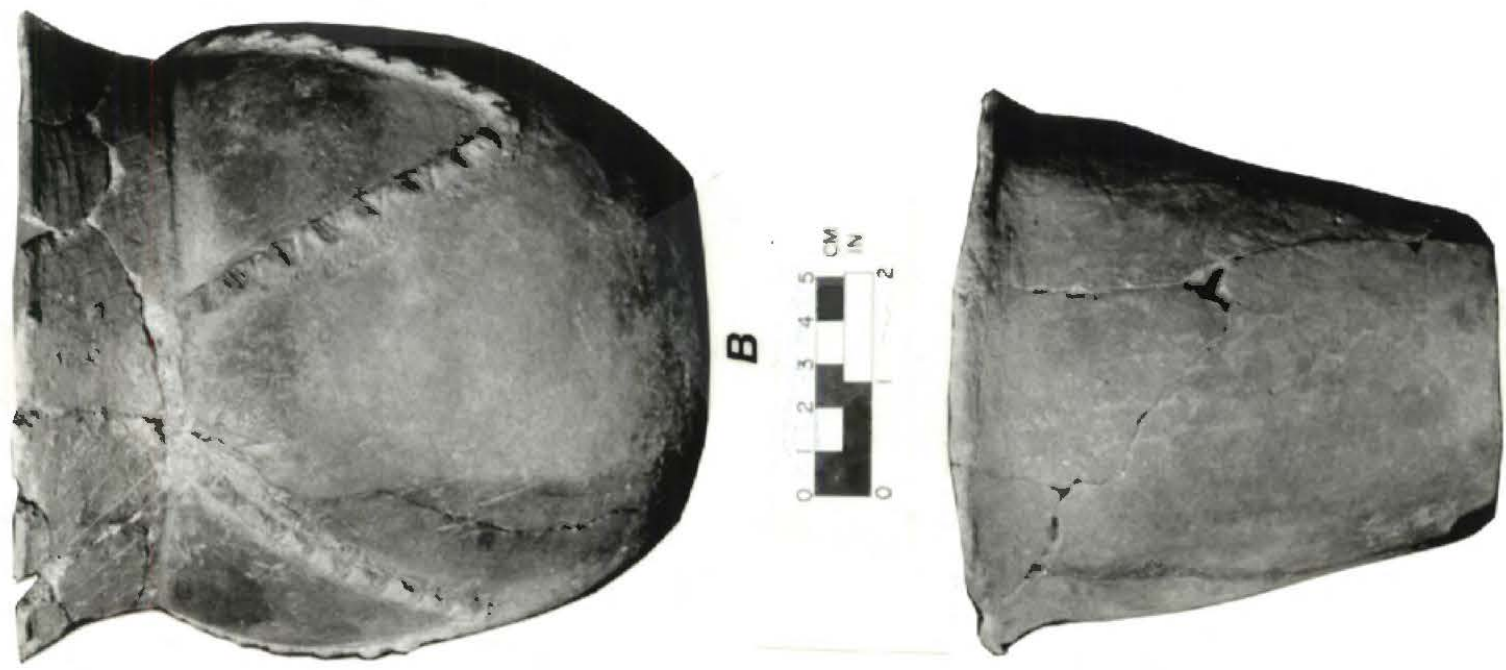

w
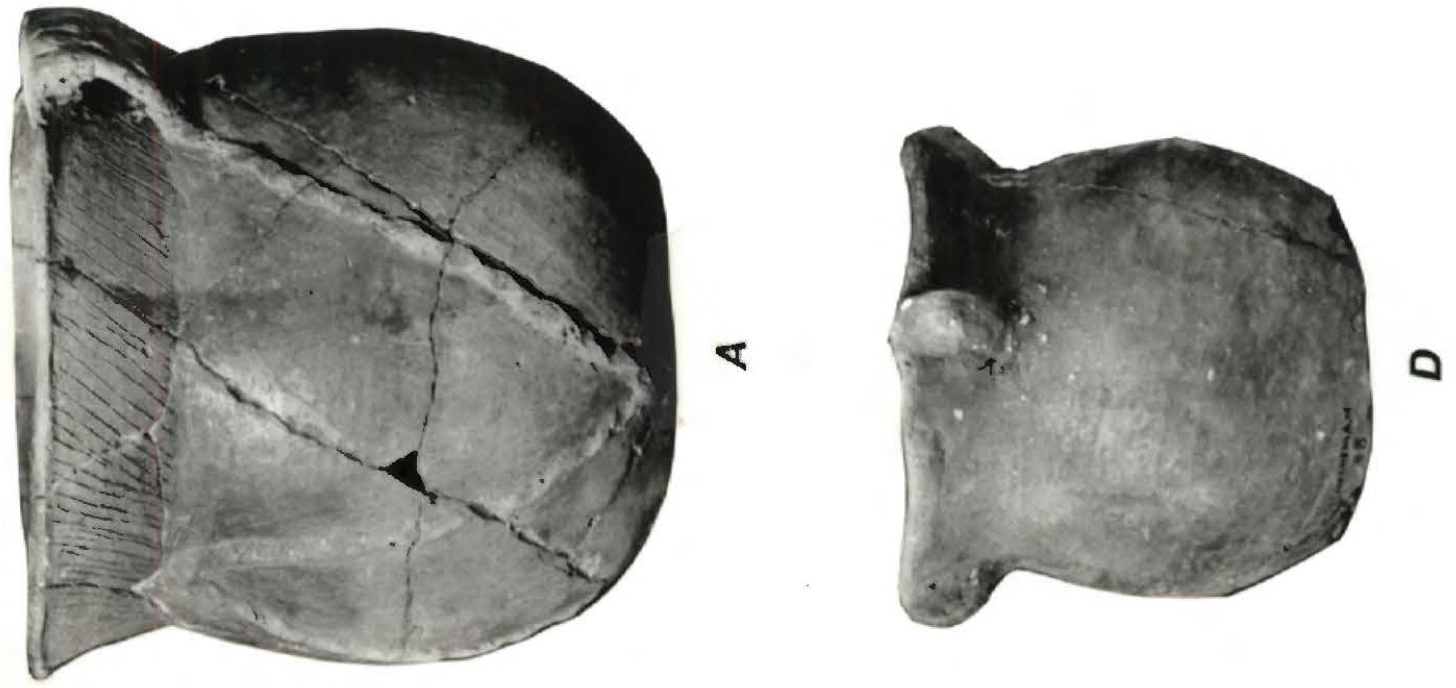

Figure 4. Middle Caddoan Jars and Bowls: a-b, incised-appliqued; c, Canton Incised; d, jar with strap handles; e, flowerpot-shaped vessel; f, Sanders Plain with interior-thickened rim. 
the Middle Caddoan component) while Maxey Noded Redware and Canton Incised predominate (see Perttula 1995:Table 9). Other vessel characteristics/attributes include increased red-slipping of bowls and bottles; the engraved serpent/snake motif is present; bowls with scalloped rims (see Figure 3c); red-slipped neckless bottles; rim effigy heads and tabtails; rim peaks; strap handles; incised, punctated, and appliqued jars (see Figure 4ac); and interior thickened rims on many red-slipped bowls (see Figure $4 \mathrm{f}$ ).

The mortuary component at the Sanders site also includes plain and engraved shell gorgets, dippers, beads, triangular inlays, and conch pendants, as well as bone beads, pigments, and copper-covered siltstone earspools (Krieger 1946:202-203). Green pigments were a common inclusion in Sanders phase burials at the Holdeman site (Perttula 1995:Table 6).

\section{References Cited}

Bruseth, J. E., D. E. Wilson, and T. K. Perttula

1995 The Sanders Site: A Spiroan Entrepot in Texas? Plains Anthropologist 40(153):223-236.

Hamilton, D. L.

1997 Observations on Caddoan Burial Practices at the Sanders Site. Bulletin of the Texas Archeological Society 68:115-133.

Krieger, A. D.

1946 Culture Complexes and Chronology in Northern Texas with Extension of Puebloan Datings to the Mississippi Valley. Publication No. 4640. The University of Texas, Austin.

Loveland, C. J.

1987 Human Skeletal Remains from the Clark and Holdeman Sites, Red River County, Texas. Bulletin of the Texas Archeological Society 57:165-181.

1994 Rowland Clark and Dan Holdeman Site Human Skeletal Remains. Journal of Northeast Texas Archaeology 4:50-60.

Perino, G.

1995 The Dan Holdeman Site (41RR11), Red River County, Texas. Journal of Northeast Texas Archaeology 6:3-65.

Perttula, T. K.

1995 A Reconsideration of the Chronological and Cultural Placement of the Mortuary Remains and Grave Goods from the Dan Holdeman Site. Journal of Northeast Texas Archaeology 6:67-87.

Wilson, D.

1997 Dental Paleopathology in the Sanders (41LR2) and Mitchell (41BW4) Populations from the Red River Valley, Northeast Texas. Bulletin of the Texas Archeological Society 68:147-159.

Wilson, D. E. and D. Cargill

1993 Stable Carbon Isotope Analysis from the Sanders Site. Caddoan Archeology Newsletter IV(3):3. 